\title{
ULTRASONIC WAVES AND STRENGTH REDUCTION INDEXES FOR THE ASSESSMENT OF THE ADVANCEMENT OF DETERIORATION PROCESSES IN TRAVERTINES FROM PAMUKKALE AND HIERAPOLIS (TURKEY)
}

\author{
ALICJA BOBROWSKA, ANDRZEJ DOMONIK \\ University of Warsaw, Faculty of Geology, Department of Geomechanics, Warsaw, Poland. \\ E-mail: a.bobrowska@uw.edu.pl; a.domonik@uw.edu.pl
}

\begin{abstract}
In constructions, the usefulness of modern technical diagnostics of stone as a raw material requires predicting the effects of long-term environmental impact of its qualities and geomechanical properties. The paper presents geomechanical research enabling presentation of the factors for strength loss of the stone and forecasting the rate of development of destructive phenomena on the stone structure on a long-time basis. As research material Turkish travertines were selected from the Denizli-Kaklık Basin (Pamukkale and Hierapolis quarries), which have been commonly used for centuries in global architecture. The rock material was subjected to testing of the impact of various environmental factors, as well as European standards recommended by the author of the research program. Their resistance to the crystallization of salts from aqueous solutions and the effects of $\mathrm{SO}_{2}$, as well as the effect of frost and high temperatures are presented. The studies allowed establishing the following quantitative indicators: the ultrasonic waves index $\left(I_{V p}\right)$ and the strength reduction index $\left(I_{R c}\right)$. Reflections on the assessment of deterioration effects indicate that the most active factors decreasing travertine resistance in the aging process include frost and sulphur dioxide $\left(\mathrm{SO}_{2}\right)$. Their negative influence is particularly intense when the stone material is already strongly weathered.
\end{abstract}

Key words: travertine, deterioration, geomechanical properties, ultrasonic diagnosis, strength

\section{INTRODUCTION}

Travertines represent carbonate rocks which, despite high porosity, were used as the main constructional material in antique structures of the Mediterranean area that have survived till present. As light building stones, they are also commonly applied as facing material in every climatic zone. Moreover, this material is used in the renovation of historical objects that have been destroyed over time (Fig. 1).

One of the largest producers of large stone blocks in the world [26], including travertine blocks, is Turkey, whereas the leading area in travertine deposits is the Denizli-Kaklık district, located in western Anatolia - Aegean Turkey, with the Pamukkale-Hierapolis deposit [27] (Fig. 2).

As commonly known, without sufficient protection and conservation, even the most resistant stone gradually undergoes aging processes. Processes of aging of stone material are caused by both natural and anthropogenic factors. Natural rock aging in the environment is a long-term process. With time, the deco- rative values and resistance of the stone gradually decrease; in the ICOMOS terminology this is known as aging or, more commonly, deterioration [2], [3], [9], [11], [12], [18], [19].

Determination of the advancement of the deterioration process is conducted using diagnostic geomechanical research methods, based on cyclic laboratory analyses adapted to local geoenvironmental processes [1], [14]-[16]. These include modelling of deterioration phenomena in increased seasoning conditions [4]-[6], [8], [10], [13], [25].

Following engineering expectations, this paper presents an attempt of a qualitative and quantitative assessment of the deterioration process. The assessment is based on integrity indexes, showing the value at which travertine resistance decreased from the initial value to the final value after seasoning in particular environmental conditions. The $I_{R c}$ index gives the value of travertine susceptibility to deterioration in relation to long-term uniaxial compressive strength changes. Moreover, the study contains a technique for the determination of the $I_{V p}$ index characterizing the changes of the elastic wave velocity due to aging 
caused by selected deterioration factors. Both indexes assume that the material that was not subject to deterioration had an index value of $\mathrm{I}=1$. Its change allows predicting intermediate deterioration stages, both directly and as percentage values.

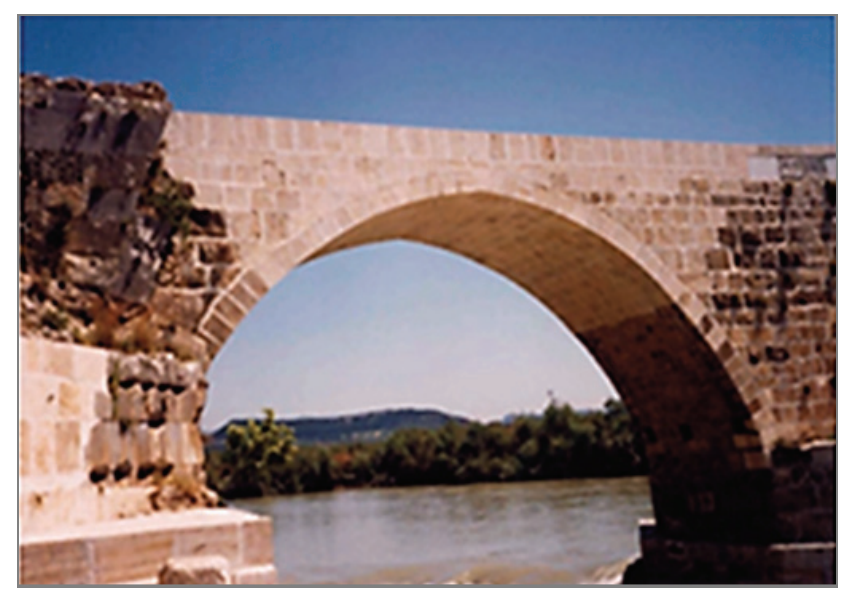

Fig. 1. Present-day use of travertine in the renovation of historical engineering objects - Belkis bridge (Turkey) (photo by J. Pinińska)

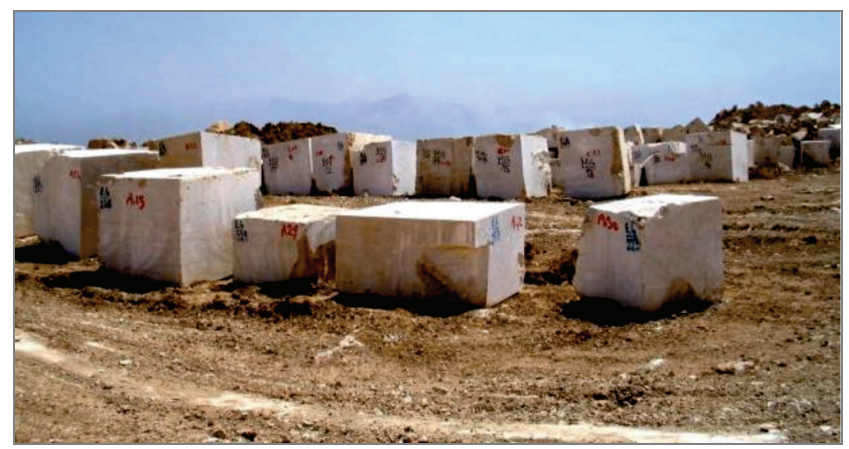

Fig. 2. Typical stone blocks produced in the Pamukkale-Hierapolis travertine quarries

\section{ASSESSMENT OF THE ADVANCEMENT OF THE DETERIORATION PROCESS (LABORATORY INVESTIGATIONS)}

Geomechanical analyses were conducted on samples of Pleistocene travertines from the Denizli-Kaklik district, collected in the presently exploited Pamukkale Quarry and a historical exposure in Hierapolis. Following the requirements of norm PN-63/B-04110, cylindrical samples with diameter $\phi=50 \pm 3 \mathrm{~mm}$ and height $h=50 \pm 3 \mathrm{~mm}$ were prepared from the travertine monoliths.
Index factor analysis of the changes of the technical parameters of travertines was conducted in conditions of frost weathering, soil crystallization, insolation, and $\mathrm{SO}_{2}$ in the presence of humidity.

Rock samples with known parameters were at first seasoned in selected geoenvironmental conditions. Analysis of frost resistance was conducted according to Polish Norm: "Stone materials. Direct determination of frost resistance PN-85/B-04102" and following the suggestions of European Norm "PN-EN 12371/2002" [21], [23]. Determination of travertine resistance to crystallization of sulphates is described in European Norm: "Natural stone research methods - determination of resistance to salt crystallization - PN-EN 12370/2001" [22]. Resistance to insolation was conducted according to an original procedure in conditions of Mediterranean and temperate climate [7]. Influence of sulphur dioxide $\left(\mathrm{SO}_{2}\right)$ on the strength of the carbonate rocks under study was conducted according to norm PN-EN 13919/2004: "Natural stone research methods - determination of resistance to aging by $\mathrm{SO}_{2}$ action in the presence of humidity" [24].

After each analysis cycle, the samples were subjected to non-destructive measurement of propagation velocity of the ultrasonic longitudinal wave [7]. The measurements were conducted using the method which directly measures the time at which the sonic impulse passes through the cylindrical sample between the transmitter and receiver. An ultrasonic defectoscope DEF8USB with dedicated software from M. Lew Labs in cooperation with IPPT was used in the investigations. In all measurements the measuring heads had a frequency of $0.5 \mathrm{MHz}$. At this frequency the sample dimensions fulfilled the requirements of an inorganic medium in relation to the length wave generated by the elastic wave heads. After the investigations modelling the impact of selected deterioration factors on the travertines, the rock samples were subject to uniaxial compressive strength analyses, following the suggestions of ISRM with application of a stiff load frame MTS-815 [13]. During the tests, in the first phase of the procedures the rock samples were loaded with a constant velocity of the axial stress increase at $0.5 \mathrm{MPa} / \mathrm{s}$. After reaching $70 \%$ of the expected destructive stress, in the second phase of the procedure, when fractures were initiated in the structure of the material, the steering system was changed and the increase of stress was regulated by the constant velocity of circumferential stress increase [20]. 


\section{RESULTS}

In engineering activities, the basic parameter assessing the construction stability is stone resistance. Resistance tests characterize only the extreme conditions of the seasoning process and do not take into consideration the gradual transformation of the structure that allows the intermediate stages to be characterized.

The assessment of the advancement of deterioration processes required therefore correlating the results of ultrasonic wave analyses with results of resistance analyses, and next - their linkage with qualitative descriptions of destruction mechanisms and changes of the pore space. Therefore, the main parameters studied were related to the resistance changes of the medium.

The leading comparative parameter was the velocity of the elastic longitudinal wave $\left(V_{p}\right)$, because ultrasonic analyses are the basic tool for continuous control of long-term advancement of the deterioration process, and due to their non-destructive character, are perfect for controlling the state of historical objects and should replace destructive methods, based on correlative data.

To ensure an extensive and quantitative assessment of the changes induced in the travertines under study, a set of comparative integrity indexes was constructed to correlate the resistance parameters with ultrasonic parameters.

\section{Ultrasonic wave index $\left(I_{V p}\right)$ and strength reduction index $\left(I_{R c}\right)$}

The strength reduction index $\left(I_{R c}\right)$ determines changes of the uniaxial compressive strength of the stone material from the initial state to the final state after seasoning. It is described by the following formula

$$
I_{R c}=\left(R_{c n} / R_{c o}\right)^{2}
$$

where

$R_{c o}$ - initial uniaxial compressive strength,

$R_{c n}$ - uniaxial compressive strength after seasoning.

The $I_{R c}$ index depends on the active environmental factor. Its values for particular seasoning conditions (factors) are presented in Table 1.

Table 2 presents the values of the ultrasonic waves index $\left(I_{V p}\right)$ indicating changes of velocity of the elastic longitudinal wave for a sample without seasoning and after seasoning, expressed by the following formula

$$
I_{V p}=\left(V_{p n} / V_{p o}\right)^{2}
$$

where

$V_{p o}$ - velocity of the longitudinal wave for a sample without seasoning,

$V_{p n}$ - velocity of the longitudinal wave for a sample after seasoning.

The $I_{V p}$ index depends also on the seasoning conditions.

Table 1. Values of the strength reduction index $I_{R c}$ in the analysed travertines

\begin{tabular}{|c|c|c|c|c|}
\hline \multirow{2}{*}{ Rock material } & \multicolumn{4}{|c|}{ Strength reduction index $I_{R c}[-]$} \\
\cline { 2 - 5 } & $\begin{array}{c}\text { after the im- } \\
\text { pact } \\
\text { of frost }\end{array}$ & $\begin{array}{c}\text { after the impact } \\
\text { of salt } \\
\text { crystallization }\end{array}$ & $\begin{array}{c}\text { after the impact } \\
\text { of temperature } \\
\text { oscillations } \\
\text { (insolation) }\end{array}$ & $\begin{array}{c}\text { after the impact } \\
\text { of } \mathrm{SO}_{2} \text { in the } \\
\text { presence } \\
\text { of humidity }\end{array}$ \\
\hline $\begin{array}{c}\text { Pamukkale } \\
\text { (HO) }\end{array}$ & $0.68^{*}$ & $0.79^{*}$ & $0.86^{*}$ & $0.71^{*}$ \\
\hline Hierapolis (HA) & $0.49^{*}$ & $0.68^{*}$ & $0.74^{*}$ & $0.57^{*}$ \\
\hline
\end{tabular}

* mean value, obtained for 6 rock samples.

\begin{tabular}{|c|c|c|c|c|}
\hline \multirow[b]{2}{*}{ Rock material } & \multicolumn{4}{|c|}{ Ultrasonic waves index $I_{V p}[-]$} \\
\hline & $\begin{array}{c}\text { after the impact } \\
\text { of frost }\end{array}$ & $\begin{array}{l}\text { after the impact } \\
\text { of salt } \\
\text { crystallization }\end{array}$ & $\begin{array}{l}\text { after the impact } \\
\text { of temperature } \\
\text { oscillations } \\
\text { (insolation) }\end{array}$ & $\begin{array}{c}\text { after the impact } \\
\text { of } \mathrm{SO}_{2} \text { in the } \\
\text { presence } \\
\text { of humidity }\end{array}$ \\
\hline Pamukkale (HO) & $0.84 *$ & $1.02 *$ & $0.96^{*}$ & $0.91 *$ \\
\hline Hierapolis (HA) & $0.65^{*}$ & $1.06 *$ & $0.94 *$ & $0.82 *$ \\
\hline
\end{tabular}

Table 2. Values of the ultrasonic waves index $\left(I_{V p}\right)$ for the analyzed rocks

* mean value, obtained for 6 rock samples. 
Comparison of the $I_{R c}$ and $I_{V p}$ indexes, assuming that the material that was not subject to deterioration is characterized by the value $\mathrm{I}=1$, clearly indicates that the largest resistance changes take place after the impact of frost, particularly in the weathered travertine from Hierapolis, where the strength reduction index $\left(I_{R c}\right)$ is low and reaches 0.49 . In this sample the lowest $I_{V p}$ index value is equal to 0.65 . The stone material from Pamukkale is characterized by much higher resistance to frost, because the $I_{R c}$ index averagely reaches 0.68 . Such high resistance is reflected in the analysis of the ultrasonic waves index $I_{V p}$ with values at 0.84 . Low resistance of weathered travertine to the impact of frost in relation to material without seasoning is distinct on the correlation diagrams of $I_{R c}$ and $I_{V p}$ indexes (Figs. 3, 4).

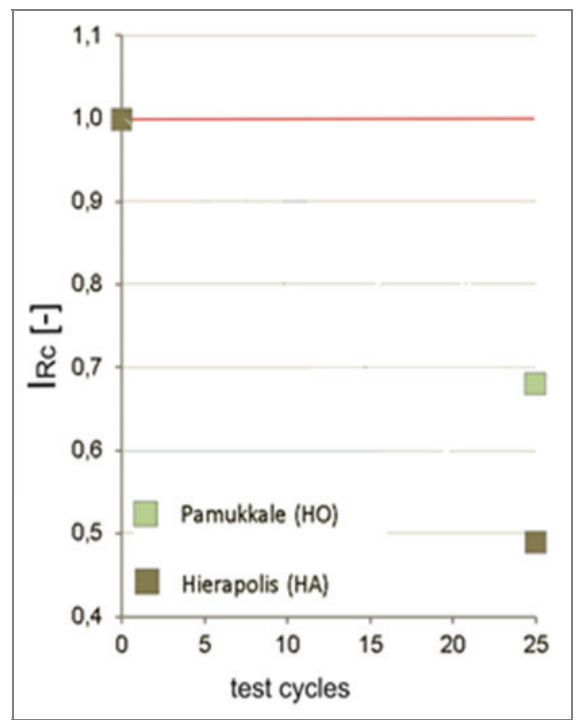

Fig. 3. Strength reduction index $I_{R c}$ after the impact of frost

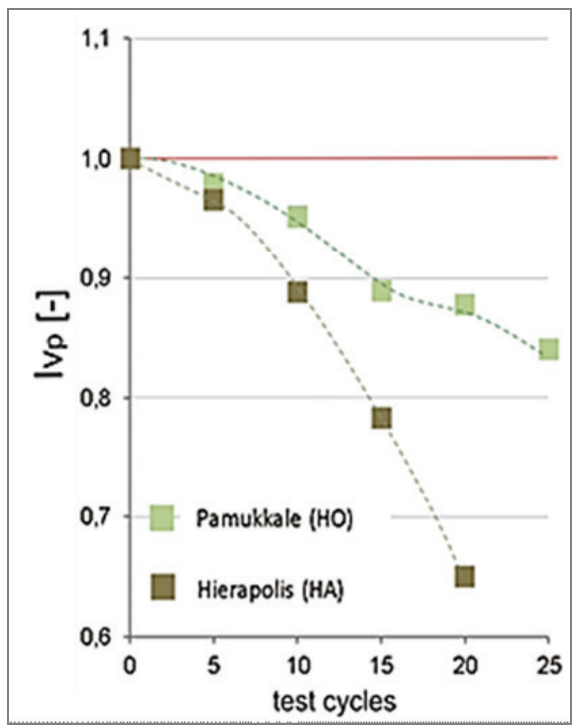

Fig. 4. Ultrasonic waves index $I_{V p}$ after the impact of frost
The impact of insulation on the integrity of travertines is reflected in the $I_{R c}$ value at 0.86 in the material from Pamukkale and at 0.74 in the material from Hierapolis. In ultrasonic measurement results this is reflected in the $I_{V p}$ values at 0.96 for the material from Pamukkale, and 0.94 for the material from Hierapolis.

Resistance prediction based on comparison of the relationships between the two indexes $I_{R c}$ and $I_{V p}$, graphically presented in Figs. 5 and 6, indicates that resistance changes may proceed nonlinearly in the initial stages of insolation. Ultrasonic diagnosis of deterioration processes in conditions when the rock skeleton dilates as a result of increased temperature is thus more correct for the final stages of deterioration.

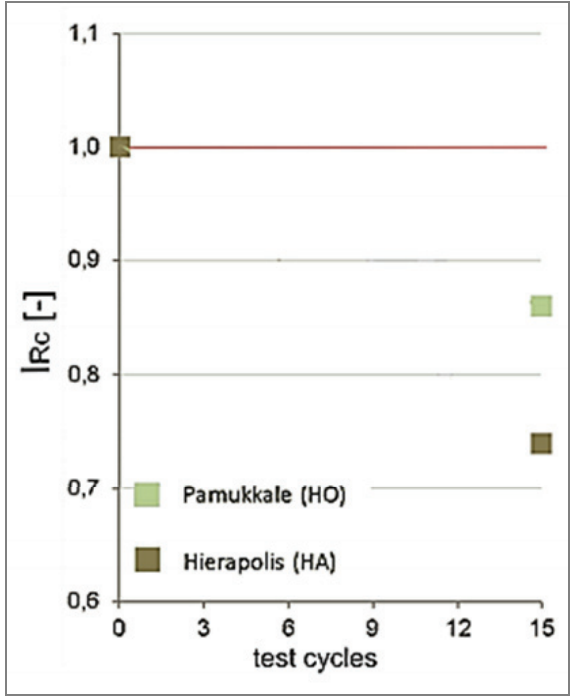

Fig. 5. Strength reduction index $I_{R c}$ after the impact of temperature oscillations (insolation)

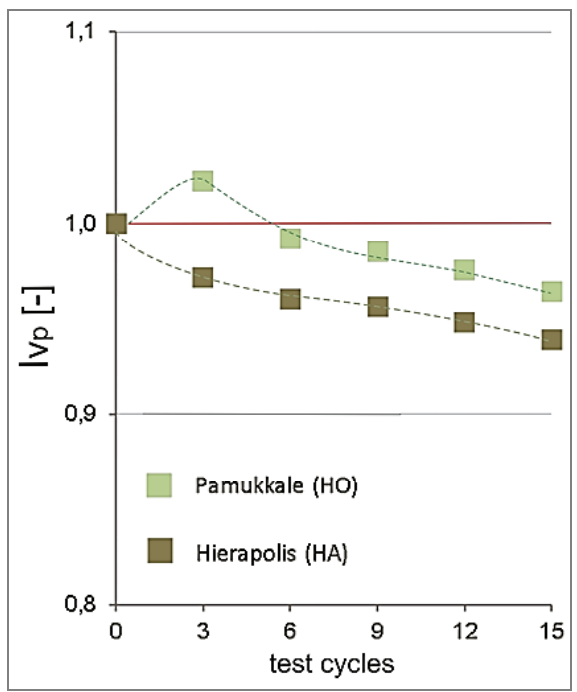

Fig. 6. Ultrasonic waves index $I_{V p}$ after the impact of temperature oscillations (insolation) 
Indexes $I_{R c}$ and $I_{V p}$ reflecting the impact of $\mathrm{SO}_{2}$ in the presence of humidity indicate a relatively high resistance of travertine from Pamukkale with $I_{R C}$ at the level of 0.71 and $I_{V p}$ at 0.88 . In travertines from Hierapolis these indexes attain values of $I_{R c}=0.57$ and $I_{V p}=0.82$, and point to low resistance.

Comparison of the $I_{R c}$ and $I_{V p}$ indexes on graphs indicates significantly high diagnostic precision of ultrasonic analyses for forecasting the resistance changes during the impact of $\mathrm{SO}_{2}$ (Figs. 7 and 8).

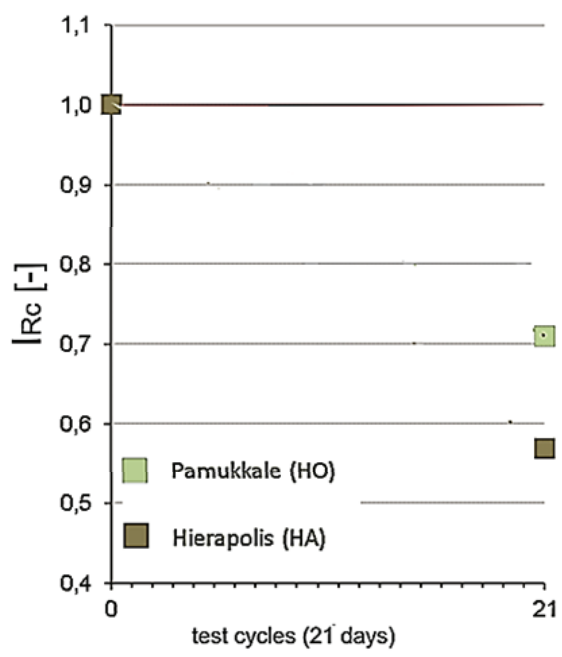

Fig. 7. Strength reduction index $I_{R c}$ after the impact of $\mathrm{SO}_{2}$ in the presence of humidity

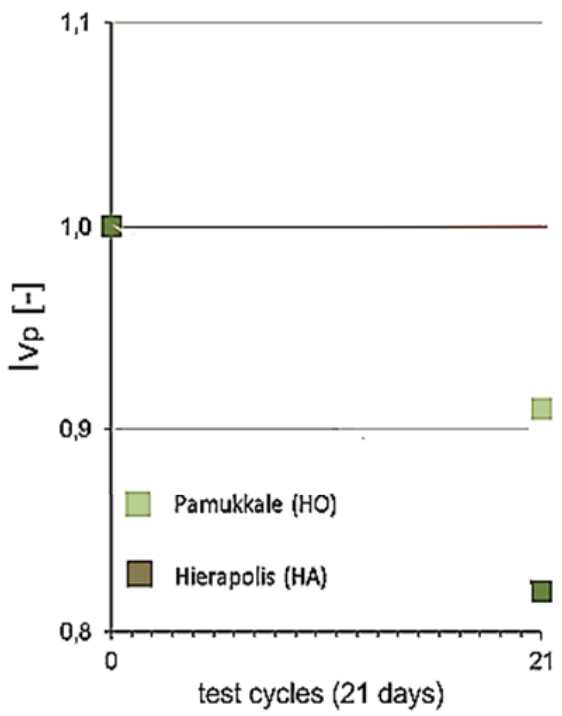

Fig. 8. Ultrasonic waves index $I_{V p}$ after the impact of $\mathrm{SO}_{2}$ in the presence of humidity

Assessing resistance changes based on the $I_{V p}$ index caused by the impact of salt crystallization can be misleading, because, as indicated above, the velocity of the elastic wave registered in the initial stages of seasoning increases due to the infilling of intergranular voids by the crystallizing soil (Fig. 9).

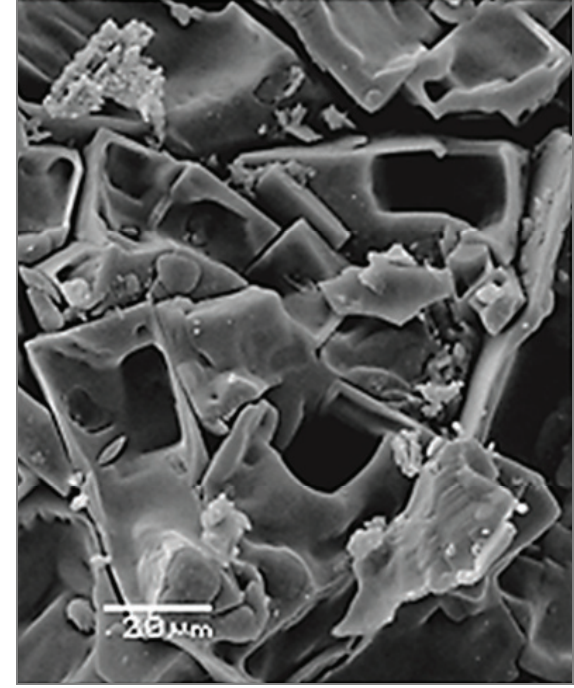

Fig. 9. Travertine pore spaces filled due to soil crystallization from solutions in the travertine from Hierapolis (with highest primary porosity)

The investigations show that after the impact of soil crystallization, the $I_{R c}$ index varies from 0.79 for the material from the active quarry (Pamukkale) to 0.68 from the material from a quarry active in ancient times (Hierapolis). Despite this, the values of the $I_{V p}$ index are equally high and reach 1.02 for the travertine from Pamukkale and 1.06 for the travertine from Hierapolis, respectively. Comparison of changes of the $I_{V p}$ index values in relation to the $I_{R c}$ index, based only on point resistance measurements, are not diagnostic enough for the structural transformations taking place in the macroporous material (Figs. 10 and 11).

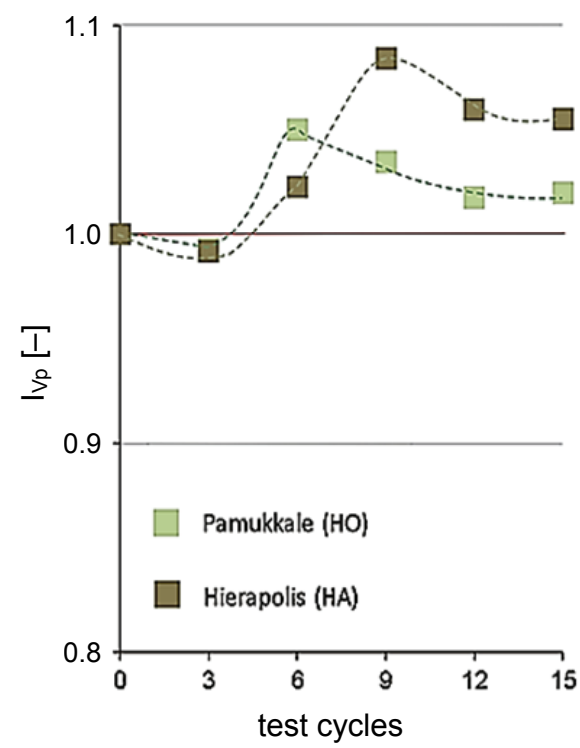

Fig. 10. Advancement of deterioration reflected in the ultrasonic waves index $I_{V p}$ after the impact of salt crystallization 


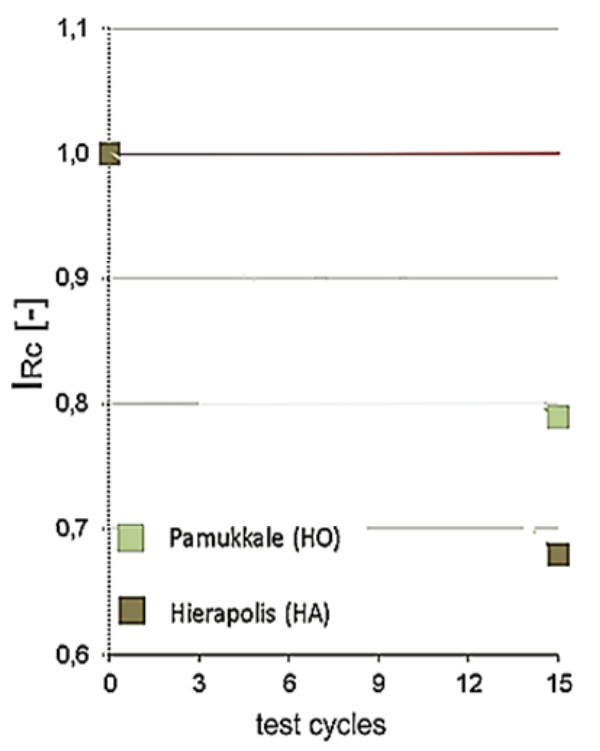

Fig. 11. Strength reduction index $I_{R c}$ after the impact of salt crystallization

\section{SUMMARY}

The assessment of deterioration effects indicates that the most active factors decreasing travertine resistance in the aging process include frost and sulphur dioxide $\left(\mathrm{SO}_{2}\right)$. Their negative impact is particularly strong when the stone material is already strongly weathered.

Integrity indexes based on non-destructive research methods reflect these trends, although the ultrasonic wave index $\left(I_{V p}\right)$ has higher values than the strength reduction index $\left(I_{R c}\right)$, which may suggest a lower final destruction of the rock structure. This is a well-known difficulty in direct comparison of static and dynamic research results [17]. In turn, ultrasonic methods better characterize the complex destruction process of the rock structure, not proceeding linearly in relation to the seasoning time.

A complex, quantitative assessment of the deterioration process with application of the $I_{R c}$ index, correlated with the $I_{V p}$ index, allows for an efficient forecast of the complex deterioration symptoms of macroporous carbonate rocks in various environmental conditions.

Despite their low resistance to the impact of frost and sulphur dioxide, travertines remain a valued decorative material due to their availability, warm colouring and original, porous, and locally even cavernous structure. These irregular, empty macroporous voids are often filled with crystallized calcite, which additionally enriches their decorative values.

\section{REFERENCES}

[1] Attia El-Metwaldi H.R., Geomechanical study of restoration and Conservation of Maadi Town Temple Fayoum Egypt, Ph.D. Thesis, Faculty of Geology, Warsaw University, 2001.

[2] Bellopede R., Marini P., The Effect of Water on The Strength of Building Stones, American Journal of Environmental Sciences, 2012a, 8/2, 158-161.

[3] Bellopede R., Marini P., Sandstone decay: from historical buildings to laboratory tests, SAHC, 2012b, 1, 691-696.

[4] BoBrowsKa A., Ultrasonic investigations in assessing rock deterioration, Geologia. Kwartalnik Akademii GórniczoHutniczej, 2009, 35(2/1), 633-639. (in Polish).

[5] Bobrowska A., Application of simple methods of Digital imaging in the assessment of the deterioration of travertines from Hierapolis (Turkey), Biuletyn PIG, 2011, 446, 111-116, (in Polish).

[6] Bobrowska A., Resistance changes in the conditions of soil crystallization and $\mathrm{SO}_{2}$ impact in selected macroporous carbonate rocks, Przegląd Geologiczny, 2013, tom 61/5, 311-314.

[7] BoBRowsKa A., Long-term processes of transformations in geomechanical properties of carbonate rocks in constructional elements, unpublished Ph.D. Thesis, Library of the Faculty of Geology, University of Warsaw, 2014, 1-163, (in Polish).

[8] DomONIK A., Resistance and deformation rock properties. Part VI. Central Western Carpathians, p. 13 and p. 14. Warsaw, Poland, Zakł. Geomech. IHiGI. Wyd. Geol. UW, 2012, (in Polish).

[9] ICOMOS. (2010). International Council on Monuments and Sites.

[10] КŁOротоWSKa A., ŁuKAsZEwsKi P., The influence of the salt mist on the deterioration of rock materials, Studia Geotechnica et Mechanica, 2014, 1, 37-46.

[11] LUKASIAK D., Resistance variability of the Godule Sandstones from Brenna in uniaxial stress conditions, Górnictwo i Geoinżynieria, Kwartalnik AGH, 2010, tom 34/2, 435-441. (in Polish).

[12] LUKASIAK D., Influence of selected destructive processes on the resistance of the Godule Sandstones from Brenna, Górnictwo Odkrywkowe, 2013, 1, 56-60, (in Polish).

[13] LuKASZEWSKI P., Deformation capability of flysch sandstones in a complex stress field, Habilitation Thesis, Warszawa, Wyd. UW, 2013, (in Polish).

[14] Pinińska J., Resistance and deformation rock properties. Kraków-Częstochowa Jura Chain, p. 5. Katalog. Z. Geom. IHiGI. W. Geol. UW, 1999, 1-79, (in Polish).

[15] PINIŃska J., Influence of elevated temperature on the mechanical properties of rocks, Prace Nauk. Inst. Geot. i Hydr. Polit. Wrock., 2007, 76, 527-534, (in Polish).

[16] PINIŃSKA J., Geomechanical properties of opokas, Górnictwo i Geoinżynieria, Kwart. AGH, 2008, 32/1, 293-302, (in Polish).

[17] PINIŃSKA J., DZIEDZIC A., Resistance and deformation properties of rocks. Part V. Lublin Region, p. 10, Descriptions and interpretations, Warsaw, Poland: Wyd. Geol. UW, 2007.

[18] Pinińska J., Bobrowska A., PAMukcu C., Ultrasonic stuides in assessing rock deterioration, Geologia, Kwart. AGH, 2009, 35/2/1, 633-639, (in Polish).

[19] Pinińska J., Bobrowska A., Pamukcu C., Deterioration processes of travertine monumental and contemporary stone structures, Geologica Balcanica, 2010, 39/1-2, 310-311.

[20] PN-84/B-04110. Determining resistance to stress (in Polish). PKN i M. Warszawa. 
[21] PN-85/B-04102. Direct determination of resistance to frost (in Polish). PKN i M. Warszawa.

[22] PN-EN 12370:2001. Methods used in the research of natural stones. Determining the resistance to soil crystallization (in Polish). PKN i M. Warszawa.

[23] PN-EN 12371/2002. Methods used in the research of natural stones. Determining the resistance to frost (in Polish). PKN i M. Warszawa.

[24] PN-EN 13919:2004. Methods used in the research of natural stones. Determining the resistance to aging caused by $\mathrm{SO}_{2}$ impact in the presence of humidity (in Polish). PKN i M. Warszawa.
[25] SkŁodowski M., Pinińska J., ŁuKASZEwski P., BobrowsKa A., Application of Rayleigh wave to diagnostics of degradation of historic construction materials, Diagnostics and structural health monitoring, 2011, 3/59, 19-24.

[26] YAĞIZ S., Overview on geo-mechanical assessments of Denizli travertines in Turkey, Proceedings of 10th International Association of Engineering Geologists Congress, Engineering Geology for Tomorrow`s Cities, 384, (in DVD), the Geological Society - London, 2006.

[27] YuZer E., ANGi S., Natural stone sector in Turkey special attention to Turkish travertine, Int. Symposium on Travertine, Denizli, 2005, 3-13. 